\title{
FROM GREEN TO ETHICAL CONSUMERS: WHAT REALLY MOTIVATES CONSUMERS TO BUY ETHICAL PRODUCTS?
}

\author{
Eliane Karsaklian, Université Sorbonne, France \\ Anthony Fee, University of Technology Sydney, Australia
}

\begin{abstract}
Ethical consumers have evolved from boycotting to consuming and ethical consumption has attracted much attention from marketing researchers recently. Several studies have been conducted to understand what motivates consumers to buy certain ethical products such as fair trade, eco-friendly or animal-friendly. While a number of disparate, and primarily descriptive, studies have identified motivations of ethical consumers towards an array of different products and in a variety of contexts, researchers are yet to develop a more generalizable framework for understanding ethical consumption motivations. In this paper, we present a framework of four universal motivations to explain why consumers buy ethical products.
\end{abstract}

\section{INTRODUCTION}

Although ethics in the marketing exchange process has been the focus of past research, the notion of consumer ethics did not receive much attention until the establishment of the consumer ethics scale by Muncy and Vitell (1992). However, few studies have been conducted with the goal of identifying the factors which motivate consumers to buy ethical products. The existing literature is based on research conducted with specific categories of ethical products, mainly fair trade products (e.g. De Pelsmacker, Driesen, et al., 2005). More often than not, they address countryspecific populations. This fact can perhaps be explained by the general belief that people might support ethical products and organizations because of altruistic values; that is, doing good to people and to the planet. Also, the growing number of ethical consumers is supported by the fact that ethical products have been trivialized by the retailers themselves. Unlike the "green consumers" who were few and needed go to specialized stores and pay more money to buy from limited products categories, ethical consumers choose their products among all product categories and brands. More and more brands are going ethical and hypermarkets and supermarkets are not only commercializing those brands but are also creating their own home brands for ethical products, and thus, making them affordable and accessible to a larger range of consumers.

\section{LITERATURE REVIEW}

\section{Ethical Consumption}

Consumption and ethical consumption have often been presented as conflicting behaviors towards the act of buying products. Ethical consumers do not deny consumption but rather choose goods that reflect their moral, ethical, and social concerns (Szmigin and Carrigan, 2006). Ethical consumption can also be viewed as the shifting of consumption from the private sphere of home and family into the public political sphere (Sassatelli, 2006). Harrison, Newholm and Shaw (2005), define ethical consumer as the one concerned with the effects of the external world around them. They undertake a range of ethical consumption practices including boycotts, positive buying, fully screened comparative ethical ratings across whole product areas, relationship purchasing, where consumers seek to educate sellers about their ethical needs, and anti-consumerism or sustainable consumerism (avoiding unsustainable products). This image of the green consumer who is against the non ethical products, brands and companies is changing and leading to a new profile of consumer: the ethical consumer who is proactive and consumes in a more responsible way. Doing so, they help planet and people to live in better conditions and use their consumer practices as a contribution to others and to themselves. It seems that this evolution aligns with what Mintzberg calls plural and social which is the best way of conciliating private and public objectives (Mintzberg, AOM Conference, Boston, 2012). According to him, social initiatives are better to reach plural objectives than social movements. Thereby we can say that ethical consumption is evolving from social movements like boycotts performed by few people, to a general mass consumption of ethical products stipulated by companies and governments. Finally, several big international groups well-known by not being ethical are progressively changing their images by purchasing ethical small companies and brands. As examples, we can cite L'Oréal which purchased the Body Shop, Innocent bought by Coca-Cola Company, and Unilever with Ben\&Jerry's. All the above described leads us to believe that ethical consumption is a sustainable trend leading consumers to make decisions differently. Thus, it is imperative that marketing researchers and practitioners understand the underlying motivations for ethical consumption. 


\section{Ethical Consumption Motivations}

Motivation theories suggest that human motives, whether cognitive or affective, are primarily geared towards individual gratification and satisfaction. They provide the theoretical basis for examining underlying reasons for why people shop. In a review of the main literature about shopping typology, Rohm and Swaminathan (2004) identified the following shopping motives among online shoppers: overall convenience/time savings (shoppers select stores based upon time and effort savings), the shopping experience (enjoy shopping as a leisure-based activity), social interaction (reference group affiliation and communicating with others having similar interests), and information seeking (search for specific information tailored to their needs).

With the number of people identifying themselves as ethical consumers on the rise (e.g. Flatters and Willmott, 2009; Hughes, 2012), the study of their motivations is paramount to marketing researchers and practitioners. Katz's (1960) typology posits that any given attitude serves one or more of four distinct personality functions: utilitarian, knowledge, ego-defensive, and value-expressive. Additionally, Smith (1973) proposed an extension of the valueexpressive function, focused on the motivation for social adjustment, in which people express attitudes or behavior that are agreeable to others. The function has also evolved to include motivations derived from relationships with others and recognizes the distinction between internal beliefs and the desire for external relationships, independent of moral values. In particular, the social function compels people to seek opportunities to interact with friends or participate in activities perceived favorably by important others (Clary et al. 1998).

Among the typologies of ethical consumption motivations, some are based on broader, generally descriptive, theories of motivation. These include Maslow's (1943) needs theory, which highlights the needs for achievement, affiliation and power, Rokeach's (1968) instrumental and terminal personal values, and the expectancy theory (Witt and Wright, 1992), which expresses the idea that motivation is a function of the attractiveness of the outcome and the expectancy of achieving that outcome. Finally, Pearce and Caltabiano's (1983) benefit segmentation has been considered a better predictor of future consumer behavior thanks to its ability to rely on causal factor rather than descriptive factors, as the previous ones.

In our research, we define motivation as "why" an individual or group have behaved or are about to perform an action (e.g. Dann, 1981). In other words, we aim at identifying what factors drive the choice of an ethical product or brand. We believe that consumers are concerned by the benefit they will obtain from the consumption of particular products. This definition aligns with both expectancy and benefit theories, as consumers are expecting to obtain specific benefits by consuming those specific products. Brinkmann and Peattie (2008) defined fair-trade shopping motives based on four variables such as public motives (ethical investing), private-social motives (social networks), private-caring motives (experience and interaction), and private-hedonism motives (excitement). Some researchers demonstrated that motivation alone is not enough for people to take the leap from traditional products to ethical consumption. For example, according to Kriesi and Westholm (2007) sustainable consumption practices stem from individuals' concerns about the present or future conditions of the environment and other people.

As described above, number of studies have developed consumer 'profiles' based on motivations. For instance, in a recent study of 'sustainable' consumers, defined as those who had bought products with fair trade or eco-friendly labels (Barkman, 2010), measured motivation by dissatisfaction, interest and civic duty. He identified four prototypical sustainable consumers: the "idealists" (recycle and save energy), the "able and willingly" (choose environment over economic growth), the "OK, I'll do it" (buy ethical products because others do), and the "unwilling responsibility-takers" (buy ethically, despite not accepting environmental protection as their responsibility). Similarly, Devitiis et al. (2008) created a typology of consumers of fair trade food in one region of Italy, identifying four discrete categories: selfish, pleasure-seeking and curious (wanted pleasure), ethical (integrate any ethical component), ethical hygienist (effective action), hygienist selfish (health concerns). Looking at motivations of e-shoppers in the US, Brown et al. (2003), highlight the existence of multiple motivations such as relationship with the seller, enjoying the act of shopping, achieve the best quality-price relationship, enjoying shopping and personal relations, valuing time and effort, being loyal to a brand or a shop and rejecting the act of shopping. Table 1 summarizes the main typologies of consumers cited in this paper.

The social dimension of ethical consumption was studied by Holt (1995) and Szmigin and Carrigan (2006). The latter propose four ways that consumers use their fairly traded consumption choices for integration: distinction, hedonistic satisfaction, love and aesthetic appreciation. Distinction highlights the fact that ethical consumption requires the consumer to distinguish themselves through proactive purchasing and rejection, as they are often less 
concerned with the price of the commodity but look for reassurance that the goods have the appropriate ethical attribute. Hedonism implies that the consumption experience itself is an end (Holbrook and Corfman, 1985). Love implies the fact that consumers demonstrate their love for one another through the care and attention we give to the purchase they make. In sum, ethical consumers are people who are influenced by environmental or ethical considerations when choosing products and services. Arguments within the sustainable consumption field demonstrate that lots of everyday choices about what to buy have little enough to do with self-interest or personal identity, but a lot to do with obligations to others, love, care, compassion, and vulnerability (Malpass et al., 2007).

The literature review presented above describes several typologies of motivations stated by different authors. Some like Maslow and Katz, for instance, were not applied to ethical consumption, but were supposed to be universal as applied to all consumption in general. The researches analyzing motivations to buy ethical products do not integrate the evolution of consumers from green to ethical consumers. In our research, we aim at highlighting the fragmenting of consumers toward both social/non social and individualistic/collectivistic orientations of ethical consumption. Indeed, green consumers were less concerned by the social aspect of consumption as their actions are basically boycotting and sanctioning unethical companies instead of conforming to reference groups. In addition, green consumers were more collective in their behavior as consumers, as their demonstrations and actions were carried out in groups. Today, ethical consumption carries considerable social factors and decision about consumption and can be made with an individualistic perspective. Thus, in this paper we aim to draw on this past literature to understand the evolution of ethical consumerism by integrating them into a new typology of motivations for buying ethical products.

In addition to the social dimension of ethical consumption, researchers have also studied the influence on environmental and contextual factors. One of the main contributions to this area has been made by Stern (1997) and his colleagues by introducing the VBN and the ABC theories. The Value-Belief-Norm (VBN) theory develops how elements of the personal domain interact and affect individuals' levels of support for the goals of social movements in general and the environmental movement in particular. It holds that such support depends on an individual's acceptance of key values shared by the movement (for environmentalism, valuing the welfare of other people, other species, and the biosphere), on them holding beliefs that particular conditions of environmental degradation threaten these values, and on them holding the further belief that something they can do would directly or indirectly help ameliorate these conditions and preserve the values.

The conceptual basis for the A-B-C (Attitude-Behavior-Context) shows that the predictive value of attitudinal variables for pro-environmental behavior depends on aspects of the context, particularly the amount of effort, expense, or inconvenience required to change the target behavior. The chief implication for policy is that the extent to which behavior can be changed by interventions in the personal domain, such as education or information, depends on the strength of contextual forces: there are times and places when personal-domain interventions are likely to be effective and others when they will predictably fail (Stern, 1999).

\section{Why do Consumers Buy Ethical Products?}

Generally speaking, consumers want attractive and usable products, thereby often disregarding higher consumption of levels of energy and materials. It is difficult to change daily routines and consumers' perceptions of sometimes unattractive environmentally friendly products. Decision making is guided by a rational evaluation of behavioural consequences (Engel et al., 1995).

Studies of the motivations for ethical consumption highlight its complexity arising from the heterogeneity among consumers and their vision of ethics and ethical products. (e.g. Lockie, Lyons et al., 2002; Shaw and Newholm, 2002; Ozcaglar-Toulouse, Shaw et al., 2006). For instance, the 2011 Green Brands Survey of more than 9000 people in 8 countries $^{1}$ shows continued growing interest in purchasing from environmentally sustainable companies, a breadth of ethical priorities, ranging from climate change to waste reduction and water management, and consumer motivations that include novelty, security and social interactions.

These complexities are not surprising given the diversity of ethical products and services available (Cowe and Williams 2010). Unlike the beginning of the "green era", when the range of ethical products was limited, ethical consumers have, now a day, the possibility of picking products from all categories, from different brands and accessible in several points of sales. Retailers, grocery stores, hyper and supermarkets are creating their own ethical

\footnotetext{
${ }^{1}$ For a summary, see: http://www.cohnwolfe.com/en/ideas-insights/white-papers/green-brands-survey-2011 [accessed 19 July 2011]
} 
brands and making them affordable and accessible to all consumers. Although there still exists a lack of clarity about the motives which lead consumers to buy ethical products, research suggest that a combination of altruistic- and selfinterests play a role in motivating ethical consumption (Freestone and McGoldrick 2008). Indeed, this variety of products and brands creates a social pressure among consumers who feel involved in this new type of consumption which is closely linked to their self-concepts.

Consumer behaviour researchers have long recognised the symbolic importance of consumption decisions (Levy 1959). Symbolic consumption offers symbolic value by expressing a meaning to significant others (Grubb and Grathwohl 1967), and this benefits the individual through enhanced self-concept and social recognition (e.g. Cherrier 2007; Devinney, Auger et al. 2010). Thus the consumption decision can be motivated by the desire to express one's self-concept; doing so allows them to reinforce their own view of themselves and achieve consistency between their behaviour and how they see themselves, based on their beliefs about their own identities, values, lifestyles, preferences, and habits (Sirgy et al., 2008). This attention to self-concept can occur at different levels: for instance, how individuals would like to be, how they believe they are perceived, how they would like to be perceived, or how they think others perceive them. What this arm of research highlights is the social reflexivity and symbolic utility of the consumption decision; motivation is also influenced by the perception we have of how others will appraise or view our choice.

This theme is picked up in research into ethical consumption, which highlights the importance of externally-directed self-concept and status attached to ethical brands and ethical consumption decisions (e.g. Newholm and Shaw, 2007; Freestone and McGoldrick, 2008). Rather than simply pro-social motives (i.e. interest in doing good for others), research suggests that ethical consumers can be motivated by social needs in two ways. The first is through belonging to a collective identity; for example, being part of a social movement by participating in collective political or civic action (e.g. Micheletti, 2003; Cherrier, 2007). In this case, the consumption experience creates a sense of identity and conformity with a collective reference group with whom consumers wish to be, or believe that they are, associated. The second is through membership to a socially distinct niche market which is able to spend, consume, use or invest ethically (Devinney, Auger et al., 2010). In this case, the moral responsibility displayed by ethical consumers runs counter to the mainstream consumption, void of civic and political participation (Bauman, 1999). Rather, it represents a collective sense of difference from the rest of society in the same way that a boutique designer brand might (Bird and Hughes 1997; Carrigan, Szmigin et al., 2004).

\section{A FRAMEWORK FOR UNDERSTANDING MOTIVATIONS FOR BUYING ETHICAL PRODUCTS}

The literature review leads us to conclude that there is a change in pattern over time, when it was about being green to a broader concept. Indeed, the broad ranges of products now available along with numerous communication campaigns ran by companies in stimulating consumers to buy their ethical products, seem to have simplified the buying process whilst complexifying the identification of real motivations to buy ethical products. It seems that a new way for identifying consumers' motivations to buy ethical products should be seen as a multifaceted one, and not a single one like doing good. The contemporary ethical consumers might be motivated by a combination of motives instead by only one.

Despite the growth in ethical consumption in recent years, and the associated increase of research in this area, most research conducted on ethical consumer motivations has been bound to specific ethical product types and/or to a specific country. This might have been pertinent when studying green consumers, as they were more "localized", in countries such as Canada, Scandinavian and Germany. However, with the worldwide proliferation of ethical products and brands, ethical consumers might represent a more universal market target, and therefore, a non country-specific framework is needed to depict their motivations to buy ethical products.

Drawing on this review of the literature, we aimed at designing a typology of motivations which could be universal, e.g., encapsulate all those described in the existing literature by generalizing them to all product categories and all countries. As a result, we identify two dimensions that shape motivations to consume ethical products. These are represented visually as the horizontal and vertical axes in Figure 1.

The first of these dimensions is the extent to which the motivation is externally directed towards others (social) or internally-directed, independent of what other people think (non-social). Social influence stems from a person's perception of how relevant others will perceive their behaviour (e.g. Pavlou and Fygenson, 2006). At the social end 
of the continuum, decisions are influenced by group norms. Comparison to or compliance with such norms is an important motivation to individuals who seek confirmation from members of the reference group. In contrast, individuals with non-social motivations act independently, following their own norms about what is right or good to do. Hence, social motivations are externally directed and relate to other individuals, while non-social motivations are not based on other people's judgment. The second dimension is the extent to which the motivation is oriented towards the self and one's individual benefits (individualistic), or towards others and the collective good (collectivist). People with individualistic motivations are most concerned with their own welfare, instead of the group welfare. In contrast, collectivist motives stimulate individuals to associate their behaviour with, and direct their behaviour towards, a group.

From these two dimensions, we identify four categories of motivations applicable to ethical consumption: (1) conformity (social, collectivist motives), (2) self-orientation (social, individualistic motives), (3) self-actualisation (non-social, collectivist motives), and (4) hedonism (non-social, individualistic motives). These categories are represented visually as the four quadrants in Figure 1 and explained in more detail below. In line with the research reviewed above, we suggest that, rather than being motivated by a single factor, people's motivations for consuming ethical products are shaped by a combination of these factors, although for each ethical consumption decision one of the four motivational forces is likely to take precedence.

1. Conformity motivations: Conformity motivations are underpinned by the desire to belong. In other words, individuals are motivated primarily by the needs of a group to which they wish to be associated. This motivation stems from the desire to be accepted to the group, and to be perceived as 'one of them' as a result of the decision. Even though consumers might not be personally convinced of the importance or the benefits of the behavior, they are motivated to do it as a way to adapt to the norms established by the group. It is acceptance to a particular group that most motivates individuals in this category. This type of motivation relates to those identified in previous researches: Ego-defensive (Katz, 1960), social adjustment (Smith, 1973), affiliation (Maslow, 1943), private-social motives (Brinkmann and Peattie, 2008 et al., 2003), “Ok, I'll do it” (Barkman, 2010), ethical hygienist (Devitiis et al., 2008).

2. Self-orientation motivations: Self-orientation motivations are influenced by personal relevance; in other words, the extent to which the decision has a direct bearing on the self and 'self concept', or the way individuals think that they are perceived by others (Freestone and McGoldrick 2008). Unlike conformity motivations, where people seek to build an image consistent with the group's values, individuals motivated by self-orientation seek to differentiate themselves. Hence, while the group is a powerful reference point (i.e. social), the individual is concerned primarily with creating a unique image that is distinct from the group (i.e. individualistic). It is the desire for self-respect stemming from a process of social comparison that leads the individual to seek this uniqueness (e.g. being seen to do 'good' or act ethically). Thus, while the benefit is primarily internal, it is derived from external approval or status.

Ethical consumers motivated by self-oriented motives will consume products or brands that are not trivialized. The scarcity or rarity of a product or a brand is their main motivation to show how different they are from "average people". They like to show how much more concerned they are about ethical issues (relative to others). This motivation is aligned with previous findings: value-expressive (Katz, 1960), power (Maslow, 1943), public motives (Brinkmann and Peattie, 2008, 2003), hygienist selfish (Devitiis et al., 2008), and distinction (Carrigan, 2006).

3. Self-actualisation motivations: Self-actualisation motivations are those in which the individual seeks selffulfilment and an enriching experience from the ethical consumption (Maslow 1943; Goldstein 1995). Drawing on Maslow's conception of a self-actualised individual, people with self-actualisation motives are driven by growth, rather than a (perceived) deficiency. They seek the experience for egoless, selfless, detached reasons, and so fulfilling the needs has underlying altruistic motivations. A defining element of this category is that the individual seeks to help others rather than themselves, and so improved welfare for others is key primary outcome.

Ethical consumers would express altruism by buying faire trade products, in order to make sure that they are helping poor people to have a better life. They would also prioritize products from companies that practice Corporate Social Responsibility. This way, they bring their contribution on supporting companies which respect human and animal welfare and that are environmentally friendly. This type of motivation is consistent with the following findings: Knowledge (Katz, 1960), achievement (Maslow, 1943), private-caring (Brinkmann and Peattie, 2008, 2003), "able and willingly" (Barkman, 2010), ethical consumers (Devitiis et al., 2008), and love (Carrigan, 2006). 
4. Hedonism motivations: In contrast to self-actualisation motivations, individuals with hedonism motivations are driven by the need for individual enjoyment or pleasure (Hirschman and Holbrook 1982). That is, the behaviour allows the consumer to feel good. The behaviour is used to advance the desire for sensory or cognitive stimulation, with the ethical aspect of the purchase producing a higher level of enjoyment, novelty, interest or excitement. The overarching motivation is feeling good, rather than doing good, and it is the quality of the service or product received that is paramount as opposed to the collective benefit (i.e. individualistic rather than collective).

From the ethical consumption viewpoint, consumers motivated by hedonism would search more by products that would do good to them, like for example, organic food on behalf of their own health. This type of motivation relates to previous researches outcomes: utilitarian (Katz, 1960), shopping experience (Rohm and Swaminathan, 2004), private-hedonism (Brinkmann and Peattie, 2008, 2003), selfish, pleasure seeking and curious (Devittis et al., 2008), and hedonistic (Carrigan, 2006).

\section{DISCUSSION}

Our review of the ethical consumption literature has enabled us to develop a framework that aggregates existing research, and present a framework of distinct motivations for ethical consumption. Such a framework is important to both scholars and practitioners because it has the potential to offer both practical and theoretical benefits. Notably, it aims to articulate a framework of motivations that is generalizable across a range of product and consumer types. For managers, the framework can help in understanding the motivations for buying ethical products across a range of product lines. Marketers should understand the motivations for consuming ethical products in order to better match marketing strategies to specific consumer groups. If there is a desire to increase the quantity and frequency of ethical consumption, marketing researchers and practitioners must understand consumers' decision making processes, and be able to compare motivational forces across multiple categories of consumers and products. To do so, it is imperative to understand the universal motivations underpinning the purchase decision, and consequently the motivational sources of these decisions. This framework represents our attempt to assist in achieving this.

\section{CONCLUSION}

This research enhances our understanding of shopping motives that are salient to the ethical consumption context. It demonstrates that the evolution from green consumers to ethical consumers requires a framework which can encapsulate the multifaceted motivations for buying ethical products across products categories and countries. Similar typologies about consumer buying/shopping motivations have been presented. Unlike the previous typologies, the framework here presented is innovative because it encapsulates the four most recurrent motivations identified in marketing research since Maslow's work back in 1943. Ethical behaviour is timely and global, as this tendency is switching from an individual level to a communitarian one, because efforts from companies in their corporate social responsibility rules, as well as legal policies, are stimulating ethical consumption via penetrating communication campaigns worldwide. However, marketing research in this area is maturing, and needs more light shed on it.

\section{LIMITATIONS AND FURTHER RESEARCH}

Although this research highlights the importance of having a universal framework for ethical consumption motivations, two limitations should be noted. Firstly, the framework is derived from a review of existing literature but is yet to be empirically tested. Secondly, while we draw on a range of studies that cut across different contexts, product categories, samples, and research methods, the four-category framework is unlikely to be comprehensive. That is, future studies may unearth additional dimensions, categories, and/or sub-categories of motivations to those already identified here. Finally, we suppose that the framework here presented might be universal. Future research should be conducted in different cultures in order to verify if all four types of motivations are represented across cultures. 
TABLES

Table 1 - Main ethical consumer's motivations typologies

\begin{tabular}{|l|l|l|}
\multicolumn{1}{|c|}{ Authors } & \multicolumn{1}{|c|}{ Topic } & \multicolumn{1}{c|}{ Motivations } \\
\hline Szmigin and Carrigan, 2006 & Fair-trade products & $\begin{array}{l}\text { Distinction } \\
\text { Hedonic satisfaction } \\
\text { Love and aesthetic appreciation }\end{array}$ \\
\hline Brikmann and Peattie, 2008 & Fair-trade products & $\begin{array}{l}\text { Public motives } \\
\text { Private-social motives } \\
\text { Private-caring motives } \\
\text { Private-hedonism motives }\end{array}$ \\
\hline Devitiis et al. 2008 & Fair-trade food in Italy & $\begin{array}{l}\text { Selfish } \\
\text { Pleasure-seeking and curious } \\
\text { Ethical } \\
\text { Ethical hygienist } \\
\text { Hygienist selfish }\end{array}$ \\
\hline Barkman, 2010 & $\begin{array}{l}\text { Idealists } \\
\text { Able and willing } \\
\text { Ok, I'll do it } \\
\text { Unwilling responsibility takers }\end{array}$ \\
\hline
\end{tabular}

\section{FIGURES}

Figure 1: Framework for understanding the motivations for buying ethical products

Social

Externally directed; norms dictated by the group.

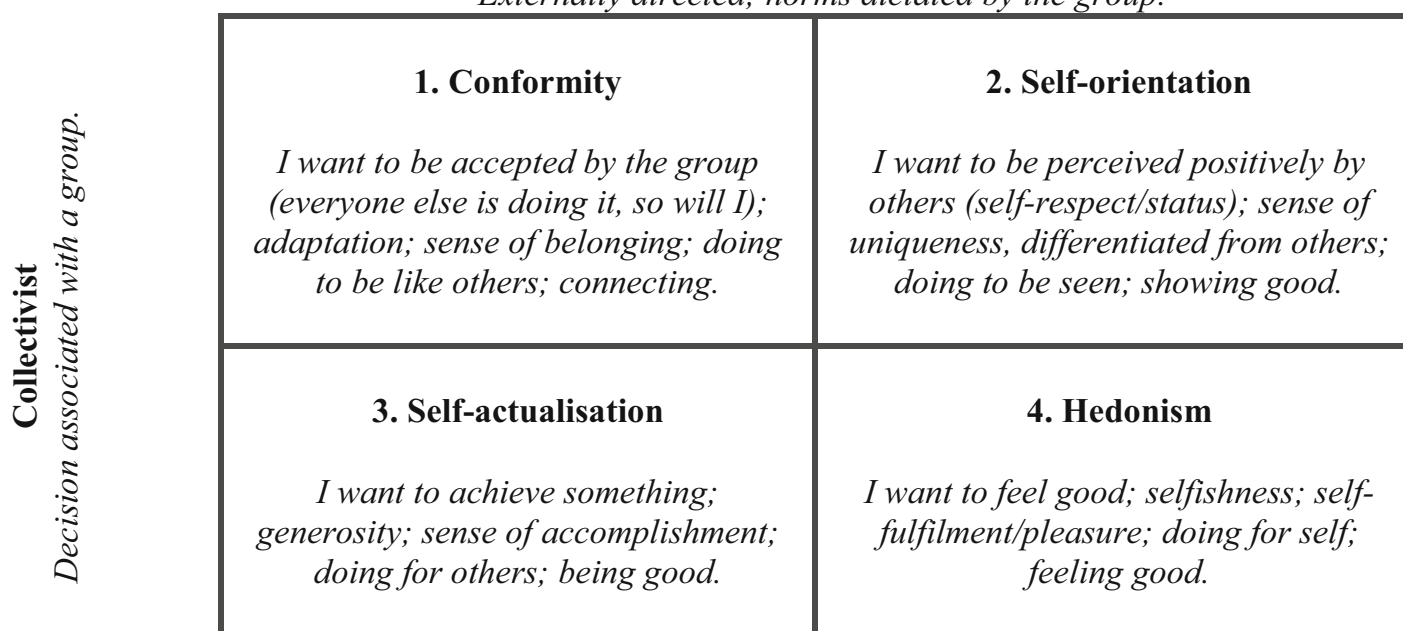

\section{Non-social}

Internal decision, independent of what others think.

\section{REFERENCES}

Barkman, H. 2010. "Motivation and capacity to be sustainable consumers: types of participant and non-participant citizens". Work in progress.

Bauman, Z. 1999. In Search of Politics. Cambridge, Polity. 
Bird, K. and D. R. Hughes. 1997. "Ethical Consumerism: The case of "fairly-traded" coffee." Business Ethics: A European Review 6(3): 159-167.

Brinkmann, J. and Peattie, K. 2008. "Consumer Ethics Research: Reframing the Debate about Consumption for Good”. EJBO Electronic Journal of Business Ethics and Organization Studies 13(1): 22-31.

Brown, M., Pope N. and Voges, K. 2003. "Buying or Browsing? An exploration on shopping orientations and online purchase intention". European Journal of Marketing. 37(11/12): 1666-1684.

Carrigan, M, Szmigin, I, \& Wright, J. 2004. 'Shopping for a better world? An interpretive study of the potential for ethical consumption within the older market', Journal of Consumer Marketing, 21: 6, 401-417.

Cherrier, H. 2007. "Ethical Consumption Practices: Co-production of self-expression and social recognition." Journal of Consumer Behaviour 6(5): 321-335.

Clary, E.G., M. Snyder, R. Ridge, J. Copeland, A. Stukas, J. Haugen, and P. Miene 1998. "Understanding and Assessing the Motivations of Volunteers: A Functional Approach". Journal of Personality and Social Psychology, 74(6): 1516-1530.

Cook, P. and N. Jackson. 2006. Valuing Volunteering. London, Chartered Management Institute and VSO.

Dann, G.M.S. 1981. "Tourist Motivation: An Appraisal”. Annals of Tourism Research, 8(2): 187-219.

Devitiis, B., D'Alessio, M.,and, Wanda Maietta, O. 2008. "A comparative analysis of the purchase motivations of Fair Trade products: the impact of social capital". 12th Congress of the European Association of Agricultural Economists - EAAE, p.1-14.

De Pelsmacker, P., L. Driesen, et al. 2005. "Do Consumers Care about Ethics? Willingness to pay for fair-trade coffee." The Journal of Consumer Affairs 39(2): 363-385.

Devinney, T. M., P. Auger, et al. 2010. The Myth of the Ethical Consumer. Cambridge, Cambridge University Press.

Engel, J., Blackwell, R. and Miniard, P. 1995. Consumer Behavior, Dryden.

Flatters, P. and M. Willmott. 2009. "Understanding the Post-Recession Consumer." Harvard Business Review 87(July/August): 106-112.

Freestone, O. M. and P. J. McGoldrick. 2008. "Motivations of the Ethical Consumer." Journal of Business Ethics 79: 445-467.

Goldstein, K. 1995. The Organism: A holistic approach to biology derived from pathological data in man. New York, Zone Books.

Harrison, R, Newholm, T., and Shaw , T. 2005. The Ethical Consumer, London: Sage.

Hibbert, S., M. Piacentini, et al. 2003. "Understanding Volunteer Motivation for Participation in a Community-based Food Cooperative." International Journal of Nonprofit and Voluntary Sector Marketing 8(1): 30-42.

Hirschman, E. C. and M. B. Holbrook. 1982. "Hedonic Consumption: Emerging concepts, methods and propositions." The Journal of Marketing 46(3): 92-101.

Holbrook, M. B. and E. C. Hirschman. 1982. "The Experiential Aspects of Consumption: Consumer fantasies, feelings, and fun." Journal of Consumer Research 9(2): 132-140. 
Holbrook, M. B. and Corfman, K. P. 1985. "Quality and Value in the Consumption Experience: Phaedrus Rides Again": in Perceived Quality: How Consumers View Stores and Merchandise, ed. Jacob Jacoby and Jerry C. Olson,Lexington, MA: Lexington Books.

Hoyer, W. D. and D. J. MacInnis. 2001. Consumer Behavior. Boston, Houghton Mifflin Company.

Hughes, A. 2012. "Corporate Ethical Trading in an Economic Downturn: Recessionary pressures and refracted responsibilities." Journal of Economic Geography 12(1): 33-54.

Holt, Douglas B. 1995. "How consumers Consume: A Typology of Consumption Practices," Journal of Consumer Research, 22, (June)1-16.

Katz, D. 1960. “The Functional Approach to the Study of Attitudes ”. Public Opinion Quarterly. (24): 27-46.

Kriesi, H. and Westholm, A. 2007. "Small-scale democracy: the determinants of action". In Citizenship and Involvement in European Democracies. Jan van Deth, José Ramon Montero and Anders Westholm (Ed.).. London and New York: Routledge.

Lockie, S, Lyons, K, Lawrence, G, \& Mummery, K. 2002. 'Eating 'Green': Motivations behind organic food consumption in Australia', Sociologia Rurals, 42: 1, 23-40.

Maslow, A. H. 1943. "A Theory of Human Motivation." Psychological Review 50: 370-396.

Micheletti, M. 2003. Political Virtue and Shopping: Individuals, Consumerism and Collective Action, New York: Palgrave MacMillan.

Muncy, J.A. and Vitell, S.J. 1992. "Consumer Ethics: An Investigation of the Ethical Beliefs of the Final Consumer". Journal of Business Research, 24(6): 297-311.

Newholm, T, \& Shaw, D. 2007. 'Studying the Ethical Consumer: A review of research', Journal of Consumer Behaviour, 6, 253-270.

Ozcaglar-Toulouse, N, Shaw, D, \& Shiu, E. 2006. "In Search of Fair Trade: Ethical consumer decision-making in France", International Journal of Consumer Studies, 30: 5, 502-514.

Pavlou, PA, \& Fygenson, M. 2006. "Understanding and Predicting Electronic Commerce Adaptation: An extension of the theory of planned behaviour", MIS Quarterly, 30, 115-143.

Pearce, P.L. \& Caltabiano, M.L. 1983. “Inferring Travel Motivation from Travellers Experience's”. Journal of Travel Research, Fall: 16-20.

Rohm, A.J. and Swaminathan, V. 2004. "A typology of online shoppers based on shopping motivations". Journal of Business Research (57): 748- 757.

Rokeach, M. 1968. Beliefs, Attitudes, and Values. San Francisco: Jossey-Bass.

Shaw, D, \& Newholm, T. 2002. 'Voluntary Simplicity and the Ethics of Consumption', Psychology and Marketing, 19: $2,167-185$.

Smith, M.B. 1973. "Political Attitudes" in Handbook of Political Psychology, J. Knutson, ed. San Francisco: JosseyBass, 57-82.

Stern, P.C. 1999. “Information, Incentives, and Proenvironmental Consumer Behavior”, Journal of Consumer Policy, (22): 461-478. 
Szmigin, I. and Carrigan, M. 2006. "Exploring the Dimensions of Ethical Consumption". European Advances in Consumer Research, (7): 608-613.

Witt, C. \& Wright, P. 1992. "Tourist Motivation: Life after Maslow". In Choice and Demand in Tourism. P. Johnson and B. Thomas (eds.), 33-55. London: Mansell. 